\title{
Sarcoma de Kaposi em paciente transplantada renal em uso de Fk-506*
}

\author{
Kaposi's Sarcoma in a renal transplant patient \\ receiving Fk-506
}

\author{
Jorge David Rocha Zanol ${ }^{1}$ \\ Sérgio Martinez Lecompte ${ }^{3}$
}

\author{
André Vicente Esteves de Carvalho ${ }^{2}$ \\ Elisa Gobbato Trez ${ }^{4}$
}

\begin{abstract}
Resumo: O Sarcoma de Kaposi (SK) é neoplasia maligna multicêntrica, cutânea e extracutânea, que tem sido descrita em pacientes transplantados renais que recebem terapia imunossupressora clássica. Este estudo descreve um caso de sarcoma de Kaposi em paciente transplantada renal recebendo FK-506, que surgiu 10 meses após o transplante.

Palavras-chave: Sarcoma de Kaposi; tacrolimus; transplante de rim.

Summary: Kaposi's sarcoma is a cutaneous and extra cutaneous multicentric malignancy that has been widely described in renal-transplant patients under classic immunosuppressive therapy. This study describes a renal-transplant patient under immunosuppressive therapy with FK-506 who presented Kaposi's sarcoma 10 months after the transplantation.

Key words: Sarcoma, Kaposi; tacrolimus; kidney transplantation.
\end{abstract}

\section{INTRODUÇÃO}

O SK é neoplasia multicêntrica cutânea e extracutânea primeiramente descrita por Moritz Kaposi, em 1872.

Existem quatro subtipos de sarcoma de Kaposi descritos na literatura. O primeiro, denominado clássico, ocorre com maior frequiência em idosos, acometendo membros inferiores, com curso crônico e incidindo mais sobre os homens do que sobre as mulheres, na razão de 10:1. É descrito também um tipo chamado africano, de curso mais agressivo e com preferência pelo acometimento de crianças. $\mathrm{O}$ terceiro subtipo é relacionado à instituição de imunossupressão iatrogênica, principalmente em transplantados. $\mathrm{O}$

\section{INTRODUCTION}

SK is a cutaneous and multicentric malignant neoplasia first described by Moritz Kaposi in 1872.

There exist four subtypes of Kaposi's Sarcoma described in the literature. The first subtype, called classic, occurs with greatest frequency in the aged, involving the lower extremities, with a chronic course and occurring more among men than women in a 10:1 ratio. Also described is a type called African, which has a more aggressive course and preferentially involving young children. The third subtype is related to administering iatrogenic immunosuppression, mainly in transplant patients.

\footnotetext{
Recebido em 08.06.2001. / Received in June, $8^{\text {th }}$ of 2001.

Aprovado pelo Conselho Consultivo e aceito para publicação em 23.03.2002. / Approved by the Consultive Council and accepted for publication in March, $23^{\text {th }}$ of 2002.

* Trabalho realizado no Serviço de Dermatologia da UFRGS. Complexo Hospitalar Santa Casa. Porto Alegre - RS, Brasil / Work done at "Serviço de Dermatologia da UFRGS. Complexo Hospitalar Santa Casa". Porto Alegre - RS, Brazil

Professor Assistente de Patologia. Serviço de Dermatologia da UFRGS. Complexo Hospitalar Santa Casa. Porto Alegre, Rio Grande do Sul, Brasil / Assistant Professor of Pathology. Dermatology Service of the UFRGS. "Complexo Hospitalar Santa Casa". Porto Alegre, Rio Grande do Sul, Brazil.

Médico residente do Serviço de Dermatologia da UFRGS. Complexo Hospitalar Santa Casa. Porto Alegre, Rio Grande do Sul, Brasil / Resident Physician of the Dermatology Service of the UFRGS. "Complexo Hospitalar Santa Casa". Porto Alegre, Rio Grande do Sul, Brazil.

Médico residente do Serviço de Dermatologia da UFRGS. Complexo Hospitalar Santa Casa. Porto Alegre, Rio Grande do Sul, Brasil / Resident Physician of the Dermatology Service of the UFRGS. "Complexo Hospitalar Santa Casa". Porto Alegre, Rio Grande do Sul, Brazil.

Médica residente do Serviço de Dermatologia da UFRGS. Complexo Hospitalar Santa Casa. Porto Alegre, Rio Grande do Sul, Brasil / Resident Physician of the Dermatology Service of the UFRGS. "Complexo Hospitalar Santa Casa". Porto Alegre, Rio Grande do Sul, Brazil.
} 
quarto e último subtipo descrito faz referência ao sarcoma de Kaposi de aparecimento concomitante à imunossupressão pelo HIV, predominante em homossexuais do sexo masculino.

A administração de novos imunossupressores, entre eles o FK-506, está relacionada com diversos efeitos colaterais, alguns novos, outros já bastante conhecidos. Entre os efeitos colaterais de maior incidência em transplantados recebendo terapia com imunossupressores encontram-se as verrugas virais ${ }^{2}$ e os carcinomas cutâneos, como o carcinoma epidermóide e o carcinoma basocelular. ${ }^{3}$

Este trabalho tem como objetivo alertar os médicos quanto a possível efeito colateral de uma droga cuja prescrição é cada vez mais freqüente, com crescente indicação de uso.

\section{RELATO DO CASO}

Paciente do sexo feminino, de 48 anos, branca, foi submetida a um transplante renal em 20 de julho de 1999 devido à insuficiência renal crônica, decorrente de rins policísticos. Sete meses após o transplante, percebeu o surgimento de lesões nodulares de cor violácea, assintomáticas, na região dorsal da mão esquerda e na região temporal esquerda. Negava a existência de lesões semelhantes em familiares, bem como doenças cutâneas prévias.

A terapia imunossupressora estava sendo realizada com FK-506 (8mg/dia), azatioprina (125mg/dia) e prednisona $(10 \mathrm{mg} / \mathrm{dia})$. A paciente também fazia uso de furosemida (40mg/dia).

Ao exame dermatológico, apresentava uma lesão nodular violácea de superfície brilhante localizada no dorso da mão esquerda (Figura 1). Na região temporal esquerda foi observada uma lesão semelhante, mantendo bordas papulosas, mas com tendência à regressão central.

A biópsia de ambas as lesões confirmou o diagnóstico de sarcoma de Kaposi (SK) (Figura 2).

A paciente foi hospitalizada para investigação de comprometimento sistêmico, e a dose de FK-506 reduzida para $4 \mathrm{mg} / \mathrm{dia}$. Foram realizadas tomografias computadorizadas de abdômen total e tórax, não sendo encontrada evidência de tumor nos exames.Também foram realizadas pesquisas de citomegalovírus, HIV, hepatite B e $\mathrm{C}$; todas com resultados negativos.

Dois meses após a redução do FK-506 para $50 \%$ da dose inicial, a lesão da região temporal esquerda continuou regredindo, não desaparecendo total-

Figura 1: Lesão nodular violácea com superfície brilhante.
The fourth and last subtype described refers to Kaposi's Sarcoma whose appearance was concomitant to immunosuppression by HIV, predominantly in male homosexuals. ${ }^{\prime}$

Administering new immunosuppressants, among them FK-506, is related to diverse side effects, some of which are novel, while the others were already known. Among the side effects of greatest incidence in transplant patients receiving immunosuppressant therapy, one finds viral warts ${ }^{2}$ and cutaneous carcinomas, such as epidermoid carcinoma and basocellular carcinoma.

The objective of this work is to alert medical doctors as to the possible side effects of a drug whose prescription is increasingly frequent, demonstrating growing use.

\section{CASE REPORT}

A 48-year old, caucasian female patient underwent a renal transplant on June 20, 1999 due to chronic renal insuffienciency, resulting from polycystic kidneys. Seven months after the transplant, the emergence of violaceous, asymptomatic nodular lesions, was noticed on the dorsal region of the left hand, and on the left temporal region of the head. Existence of similar lesions among the patient's relatives is negative, as well as any previous cutaneous pathologies.

Immunosuppressant therapy was carried out with FK-506 (8mg/day), azathioprine (125mg/day) and prednisone (10mg/day). The patient also made use of furosemide (40mg/day).

In the dermatological examination, a purple nodular lesion appeared with a shiny surface located on the back of the left hand (Figure 1). On the left temporal region a similar lesion was observed, having papulous edges, but with a tendency toward central regression.

The biopsy of both lesions confirmed the diagnosis of Kaposi's sarcoma (SK) (Figure 2).

The patient was hospitalized for investigation of systemic exposure, and the FK-506 dose was reduced to $4 \mathrm{mg} /$ day. Computerized tomographies were carried out of the whole of the abdomen and thorax, with no tumor evidence being encountered in the tests. Searches for cytomegalovirus, HIV, Hepatitis $B$ and $C$, were also conducted, the results of which were all negative.

Two months after reducing the FK-506 to 50\% of the initial dose, the lesion of the left temporal region

Figure 1: Violaceous nodular lesion with shiny surface. 


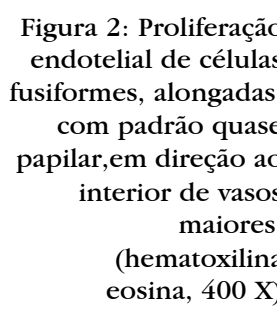

mente, e a lesão do dorso da mão esquerda permaneceu inalterada. A escolha terapêutica foi a exérese cirúrgica das lesões.

\section{DISCUSSÃO}

Apesar de existirem controvérsias quanto à origem do tumor, sabe-se que fatores infecciosos, genéticos, sociais, imunológicos e endócrinos influem na patogênese e no curso da doença. A associação com herpes-vírus 8 pode ser encontrada em todas as formas do $\mathrm{SK}^{4}{ }^{4} \mathrm{e}$, em pacientes transplantados, existe evidência de que a transmissão do vírus possa ocorrer a partir do doador, contaminando o receptor por meio do órgão transplantado. ${ }^{5}$

Excluindo-se as formas clássicas - a epidêmica relacionada ao HIV e a endêmica africana - o SK tem ocorrido com freqüência em pacientes transplantados renais que estejam recebendo terapia imunossupressora clássica (corticóides e azatioprina) ou ciclosporina, mas não tem sido observada a ocorrência de SK como uso de novas drogas imunossupressoras. Entre esses novos medicamentos encontra-se o FK-506, um derivado do fungo Streptomyces tsukabaensis. O fármaco, desenvolvido em 1983, é 10 a 100 vezes mais potente do que a ciclosporina, e seu uso progressivamente maior em transplantados renais tem ocorrido não apenas devido a sua potência, mas à menor nefrotoxicidade (37 vezes menos nefrotóxico do que a ciclosporina). ${ }^{6}$

Em meio a transplantados renais em uso azatioprina e corticóide, a incidência de SK é de 3\%, enquanto nos pacientes que utilizam ciclosporina isoladamente ou em associação com terapia imunossupressora clássica a incidência do tumor é de $8 \% .^{7}$ Atualmente, a ocorrência de SK tem sido relatada em transplantados hepáticos que estejam recebendo FK-506, ${ }^{7,8}$ mas não em transplantados renais, que perfazem um grupo consideravelmente maior de pacientes.

Na medida em que se verifica o elevado número de transplantes que vêm sendo realizados - e com o uso de novos agentes imunossupressores, entre eles o FK-506 - é provável que nos próximos anos venha a ocorrer elevação na freqüência de SK em pacientes transplantados.

\section{DISCUSSION}

Though controversies exist as to how the tumor originates, it is known that infectious, genetic, social, immunological and endocrinal factors prevail upon the pathogenesis and course of the disease. The association with Herpesvirus 8 can be found in all of the forms of SK, ${ }^{4}$ and, in transplant patients, there is evidence that transmission of the virus can occur from the donor, thereby contaminating the recipients by means of the transplanted organ.

With the exception of the classic forms-the epidemic related to HIV and the form endemic to Africa-SK has occurred frequently in renal-transplant patients that were undergoing traditional immunosuppressant therapy (corticoids and azathioprine) or cyclosporine, but the occurrence of SK has not been observed with new immunosuppressant drugs. Among the new medications, one finds FK-506, a derivative of Streptomyces tsukabaensis fungus. Developed in 1983, the medicine is 10 to 100 times stronger than cyclosporine, and its progressively greater use among renal transplant patients has occurred not especially due to its potency, but to its lower nephrotoxicity (37 times less nephrotoxic than cyclosporine). ${ }^{6}$

In the course of the renal transplant process with azathioprine and corticoid use, the incidence of SK is 3\%, while in patients using cyclosporine alone or in association with classic immunosuppressant therapy, tumor incidence is $8 \% .^{7}$ Currently, the occurrence of SK has been related to hepatic transplant patients receiving FK-506, but not in renal transplant patients, ${ }^{7,8}$ that make up a considerably larger group of patients.

Given the high number of transplants that are being carried out-and with the use of new immunosuppressant agents, FK-506 among them-it is probable that in the coming years there will be an increase in the frequency of $S K$ occurring in transplant patients. 


\section{REFERÊNCIAS / REFERENCES}

1. Prieto V, Shea C, Selected cutaneous vascular neoplasms: A review. Dematologic Clin 1999;17(3) 507-520

2. Smith SR, Viral infections after renal transplantation Am J Kidney Dis 2001; 37(4): 659-76

3. Gupta A, Cardella C: Cutaneous malignant neoplasms in patients with renal transplants. Arch Dermatol 1986; 122(11): 1288-93

4. Moore PS, Chang Y. Detection of herpesvirus-like DNA sequences in Kaposi' sarcoma in patients with and those without HIV infection. N Engl J Med 1995;332:1181-5

5. Regamey N, Tamm M, Wernli M, et al. Transmission of Human
Herpesvirus 8 infection from renal-transplant donors to recipients. N Engl J Med 1998;339:1358-63

6. Goto T, KinoT, Hatanaka H, et al. Discovery of FK-506, a novel immunosuppresant isolated from streptomyces tsukubaensis. Transplant Proc 1987; 19 (Suppl. 6):4-8

7. Kadry Z, Bronsther O, Van Thiel DH, et al. Kaposi's sarcoma in two primary liver allograft recipients occurring under FK-506 immunosuppression. Clin Transplantation 1993;7:188-94

8. Rezeig M, Fashir B, Hainau B, et al. Kaposi's sarcoma in liver transplant recipients on FK-506. Transplantation. 1997;63:1520-40

ENDEREÇO PARA CORRESPONDENCIA: / MAILING ADDRESS:

André Vicente Esteves de Carvalbo

Av. Pereira Passos, 480 / 204 A

Vila Assunção Porto Alegre RS 91900-240

Tel/Fax: (51) 32418388 /32865150

E-mail:avec@terra.com.br 